\title{
Recovery of Copper from Copper Sulfide Concentrate by Sulfation Roasting
}

\author{
Yaming Zhao', Yanan Hou'1, Yuguo Cui ${ }^{2}$, Hongwei Liang1*, Luanning Li ${ }^{1}$ \\ ${ }^{1}$ College of Chemistry, Jilin University, Changchun, China \\ ${ }^{2}$ Jilin Province Wan Guo Gold Co. Ltd., Ji'an, China \\ Email: ${ }^{*}$ lianghw@jlu.edu.cn
}

Received 17 January 2015; accepted 6 February 2015; published 11 February 2015

Copyright (C) 2015 by authors and Scientific Research Publishing Inc.

This work is licensed under the Creative Commons Attribution International License (CC BY). http://creativecommons.org/licenses/by/4.0/

(c) (i) Open Access

\begin{abstract}
Sulfation roasting was studied to extract copper from the copper sulfide concentrate. Sodium sulfite was added as sulfation agent to the copper sulfide concentrate during roasting in this study. Sulfur removal rate at different roasting temperatures was investigated, and the effects of roasting temperature, roasting time, and the amount of sodium sulfite on copper extraction were studied. Copper extraction higher than $96 \%$ was achieved at optimum roasting conditions.
\end{abstract}

\section{Keywords}

\section{Sulfation Roasting, Copper Sulfide Concentrate, Copper Extraction}

\section{Introduction}

In the last three decades, the economic conditions and the increasingly stringent environmental legislation worldwide have led metallurgical industry more difficult to develop. In addition, copper resources become increasingly depleted and the number of low-grade refractory copper ore grows day after day. Therefore, more attention must be paid to develop a low-cost, environment-friendly and high economic benefits process of recovering copper from ore. The extraction of copper from ore has commonly been performed using mainly pyrometallurgical, hydrometallurgical, and biochemical processes [1]-[3]. In traditional pyrometallurgical process, various gases released produced unacceptable air pollution, and metallurgy equipments always suffered serious erosion, leading to high production cost. Biochemical processes are mostly popular in processing the low-grade tailings or abandoned ore. While the use of this process is restricted by the strict growth environment such as temperature, $\mathrm{pH}$, oxygen concentrate and light condition of microorganism and the long leaching period. However, hydrometallurgical process does not have the problems mentioned before. Therefore, hydrometallurgical

\footnotetext{
"Corresponding author.
}

How to cite this paper: Zhao, Y.M., Hou, Y.N., Cui, Y.G., Liang, H.W. and Li, L.N. (2015) Recovery of Copper from Copper Sulfide Concentrate by Sulfation Roasting. International Journal of Nonferrous Metallurgy, 4, 9-13. 
process becomes the most viable and promising approach to treat copper sulfide ore in metallurgy fields. In hydrometallurgical process, the most widely used pretreatment process is roasting before leaching. There are three common roasting methods: oxidation roasting, chlorination roasting and sulfation roasting. Oxidation roasting needs high roasting temperature and copper will suffer a loss by generating copper ferrite. The exhaust gas $\left(\mathrm{SO}_{2}\right.$, $\mathrm{Cl}_{2}, \mathrm{HCl}$ ) from the furnace in chlorination roasting process is a threat to the environment. In sulfation roasting, copper was mainly formed to soluble sulfate by water or dilute acid after roasting. Mostly this method is applied to pretreatment of copper concentrate with high percentage of sulfur. A sulfate promoter can change the roasting atmosphere from oxidation to reduction, with releasing sulfur dioxide, turning metal oxides and sulfides to soluble metal sulfate [4]. Pyrite, sulfur, and sulfuric acid are the sulfate promoters normally used to produce the reductive atmosphere [5]-[8]. Prasad and Pandey studied the sulfation roasting of the mixture of copper-iron sulfides and copper sulfide formed copper sulfate, whereas iron sulfide converted mostly to hematite at $500^{\circ} \mathrm{C}$ [9].

In the present work, a sulfation roasting-acid leaching process that associated pyrometallurgical and hydrometallurgical methods has been used for the recovery of copper from a copper sulfide concentrate. The reactions investigated show an enhanced recovery of copper from its concentrate into a leachate which is almost devoid of iron. Suitable roasting temperatures, roasting time and a proper amount of addition have been explored in this study.

\section{Materials and Methods}

\subsection{Materials}

A flotation copper sulfide concentrate collected from a copper smelting plant from Jilin province was used as the material for this study. Its chemical composition is presented in Table 1 in which metal components were determined by AAS, ICP-AES, X-Ray Fluorescence (XRF) and chemical analysis.

\subsection{Experiment}

\subsubsection{Sulfation Roasting-Leaching Process}

The sulfation roasting-leaching experiments were carried out at a laboratory scale (2 g). The addition of $\mathrm{Na}_{2} \mathrm{SO}_{3}$ and copper sulfide concentrate were mixed well in a agate mortar, followed by roasting in a muffle electric furnace. The roasted sample was then cooled to room temperature and leached with $5 \% \mathrm{H}_{2} \mathrm{SO}_{4}(\mathrm{~V} / \mathrm{V})$ at room temperature for $4 \mathrm{~h}$ with magnetic stirrer of $400 \mathrm{r} / \mathrm{min}$, liquid/solid ratio 10:1. The slurry was filtered and the residue was washed thoroughly several times with dilute sulphuric acid, distilled water and dried. Finally, the copper content in the leached residue was analysed. The reader should note that any units shown in the text as \% represent a weight/weight percentage composition. In all the experiments, AAS (PGENERAL, TAS990) was used to determine the content of copper by standard procedures.

\subsubsection{Sulfur Removal by Roasting}

The sulfur content rested in the roasted sample of different roasting conditions was analysed by combustion iodometry method. And the sulfur oxidation ratio was calculated.

\section{Result and Discussion}

\subsection{Effect of Roasting Temperature}

\subsubsection{Effect of Roasting Temperature on Sulfur Removal Rate}

Roasting temperature was the key factor considered during sulfation roasting. Complex copper sulfides decomposed sufficiently and less copper sulfate decomposed were the key step to achieve high copper extraction. When the roasting temperature is no higher than $650^{\circ} \mathrm{C}$, there would be mainly metal sulfates and sulfur dioxide formed. Otherwise sulfates would be decomposed to oxides and sulfur trioxide above $650^{\circ} \mathrm{C}$ [10]. In order to

Table 1. Chemical composition of copper sulfide concentrate (wt\%).

\begin{tabular}{rcccccccccc}
\hline $\mathrm{Cu}$ & $\mathrm{S}$ & $\mathrm{Fe}$ & $\mathrm{Pb}$ & $\mathrm{Zn}$ & $\mathrm{C}$ & $\mathrm{Co}$ & $\mathrm{Ni}$ & $\mathrm{Au}^{*}$ & $\mathrm{Ag}^{*}$ \\
\hline 20.32 & 30.85 & 35.40 & 0.51 & 0.85 & 0.51 & 0.01 & 0.002 & 1.09 & 138.78 \\
\hline * g/t. & & & & & & & & & &
\end{tabular}


achieve good sulfation results, maximum roasting temperature was $650^{\circ} \mathrm{C}$ in this paper. And sulfur removal ratio was calculated based on the sulfur dioxide exhausted. As copper turned into copper sulfate during sulfation roasting, it is important that how much sulfur removed and remained in the roasted ore.

Seen from Figure 1, the transformation ratio of sulfur dioxide enhanced from $75 \%$ to $92 \%$ when the roasting temperature ranged from $450^{\circ} \mathrm{C}$ to $650^{\circ} \mathrm{C}$. This phenomenon may related to the roasting kinetic mechanism. It is also obvious that $\mathrm{Na}_{2} \mathrm{SO}_{3}$ can change the amount of sulfur dioxide formed during the roasting process. This may change the copper formation, either.

\subsubsection{Effect of Roasting Temperature on Copper Extraction}

Roasting temperature has an important influence on copper extraction. The influence of roasting temperature on copper extraction with different amount of $\mathrm{Na}_{2} \mathrm{SO}_{3}$ was shown in Figure 2. Below $500^{\circ} \mathrm{C}$, the increase in roasting temperature was found to have a significant effect on copper recovery. When there was no $\mathrm{Na}_{2} \mathrm{SO}_{3}$ added, copper extraction decreases rapidly above $550^{\circ} \mathrm{C}$ due to the decomposition of copper sulfate to other less soluble compounds. Tumen and Bailey [4] [11] proposed this phenomenon as following reactions:

$$
\begin{gathered}
2 \mathrm{CuSO}_{4} \rightarrow \mathrm{CuO} \cdot \mathrm{CuSO}_{4}+\mathrm{SO}_{2}+\frac{1}{2} \mathrm{O}_{2} \\
\mathrm{CuO} \times \mathrm{CuSO}_{4} \rightarrow 2 \mathrm{CuO}+\mathrm{SO}_{2}+\frac{1}{2} \mathrm{O}_{2}
\end{gathered}
$$

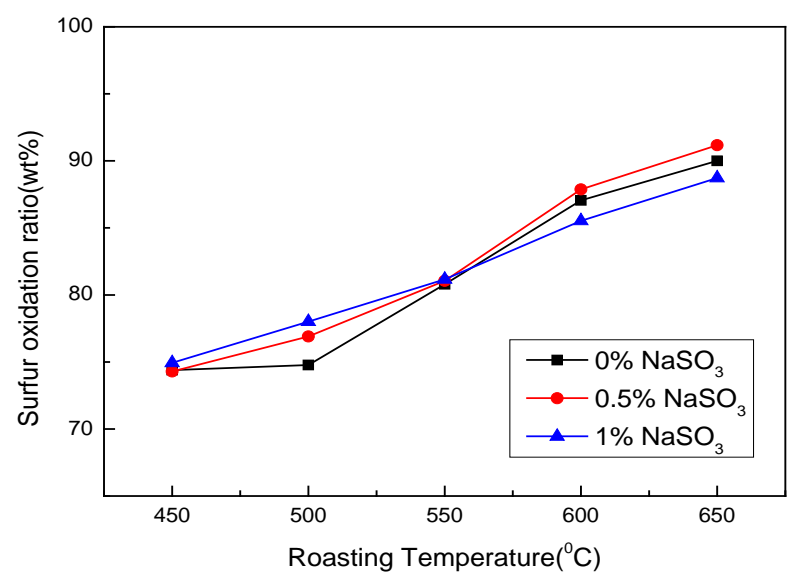

Figure 1. Effect of roasting temperature on sulfur oxidation rate.

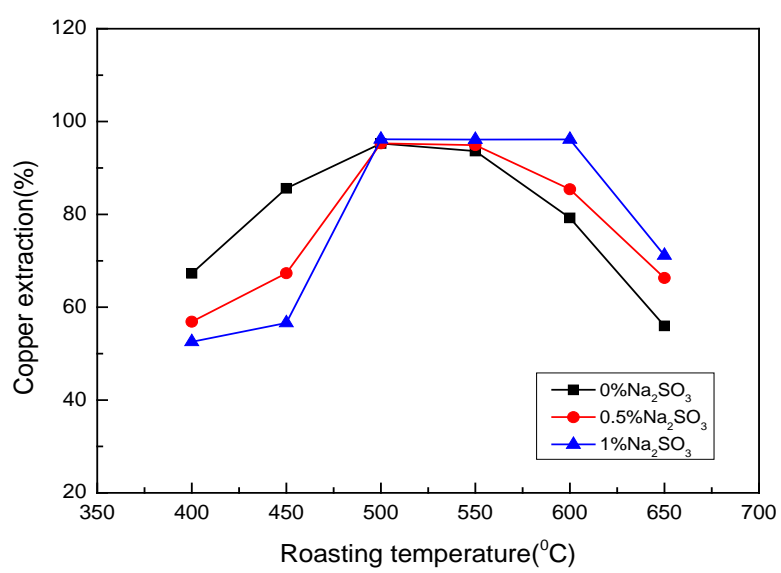

Figure 2. Effect of roasting temperature on copper extraction (roasting time: $2 \mathrm{~h}$ ). 
However, when $1 \% \mathrm{Na}_{2} \mathrm{SO}_{3}$ was added, the copper extraction wasn't down until $650^{\circ} \mathrm{C}$. This indicated that $\mathrm{Na}_{2} \mathrm{SO}_{3}$ can improve the degree of sulfating at high temperature. One possible reason is that the addition of $\mathrm{Na}_{2} \mathrm{SO}_{3}$ could prevent the decomposition of copper sulfate. Another possible reason is the exist of some complex sulfating reactions caused by the change of the oxidize and reductive roasting atmosphere in the furnace [5]. Based on these results, $500^{\circ} \mathrm{C}$ was selected as the appropriate temperature for the roasting step.

\subsection{Effect of Roasting Time on Copper Extraction}

Leaching with $5 \% \mathrm{H}_{2} \mathrm{SO}_{4}$ was carried out on the roasted samples after different roasting times and the results are shown in Figure 3. It is observed that the extraction of copper increase with roasting time up to $2 \mathrm{~h}$. Further increases have no obvious improvement on copper extraction possibly due to the composition of the other complex metal sulfates. On the other hand, it is maybe because some unsulfation reactions happened. Take the associated energy cost into account, the optimum roasting time was fixed at $2 \mathrm{~h}$.

\subsection{Effect of the Amount of $\mathrm{Na}_{2} \mathrm{SO}_{3}$ on Copper Extraction}

Among the effective factors in the roasting process, the amount of $\mathrm{Na}_{2} \mathrm{SO}_{3}$ added was then taken into consideration while the roasting time were kept constant at $2 \mathrm{~h}$. In Figure 4, it is observed that copper extraction increased from $79 \%$ to $93 \%$ with the $\mathrm{Na}_{2} \mathrm{SO}_{3}$ increased from $0.1 \%$ to $1 \%$ (wt). When the roasting temperature

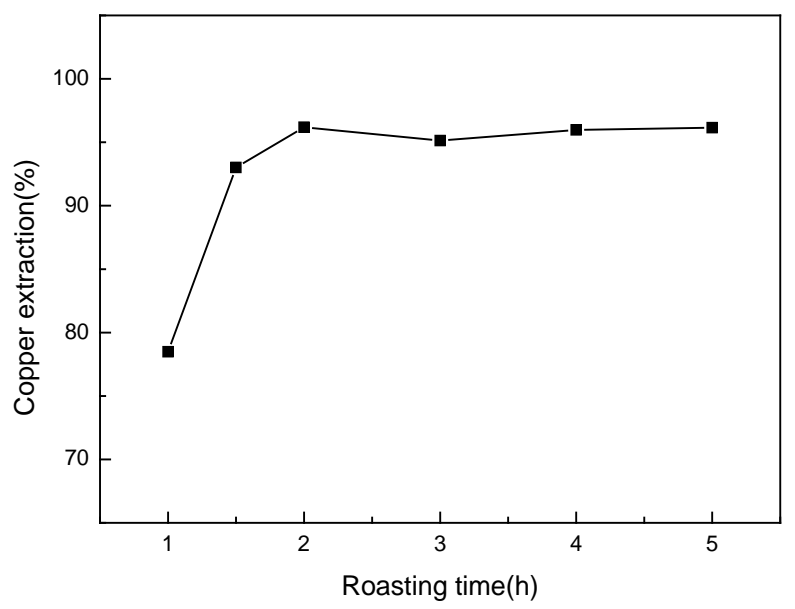

Figure 3. Effect of roasting time on copper extraction $\left(500^{\circ} \mathrm{C}\right.$, $1 \% \mathrm{Na}_{2} \mathrm{SO}_{3}$ ).

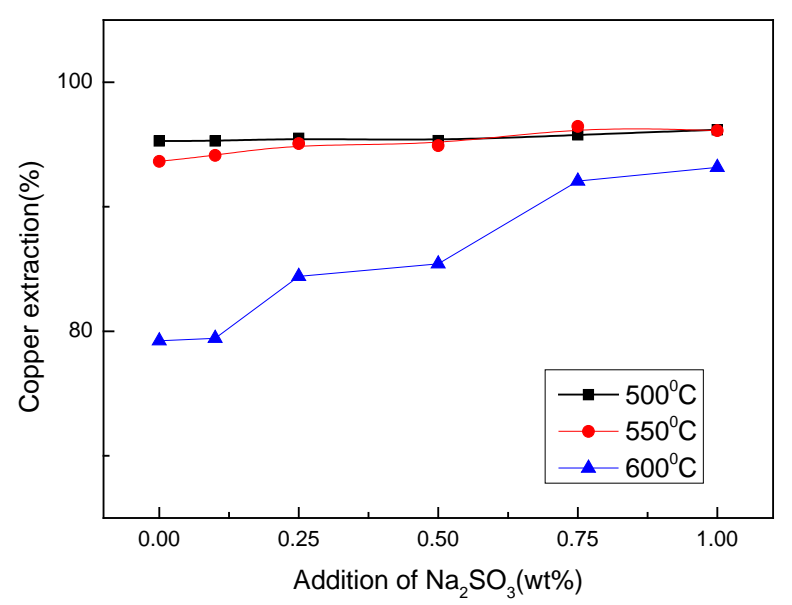

Figure 4. Effect of $\mathrm{Na}_{2} \mathrm{SO}_{3}$ amount on copper extraction (roasting time: $2 \mathrm{~h}$ ). 
fixed at $600^{\circ} \mathrm{C}$. However, the extraction of copper is almost independent of $\mathrm{Na}_{2} \mathrm{SO}_{3}$ added at $500^{\circ} \mathrm{C}$ and $550^{\circ} \mathrm{C}$. It is apparent that the sulfate promoter $\mathrm{Na}_{2} \mathrm{SO}_{3}$ only improved the copper extraction at high temperature. That possible reason is that $\mathrm{Na}_{2} \mathrm{SO}_{3}$ can change the oxidize and reductive atmosphere and prevent the decomposition of copper sulfate at high temperature. The detail roasting reaction mechanism will be studied in the future work.

\section{Conclusion}

During sulfate roasting, copper extraction is mainly affected by roasting temperature, roasting time and $\mathrm{Na}_{2} \mathrm{SO}_{3}$ addition amount. The optimum roasting temperature and time were $500^{\circ} \mathrm{C}-550^{\circ} \mathrm{C}$ and $2 \mathrm{~h}$, respectively. At the optimum conditions, there was about $96 \%$ of copper leached out. The sulfation promoter $\mathrm{Na}_{2} \mathrm{SO}_{3}$ only improved the copper extraction at high roasting temperature. It couldn't improve the sulfation effect when the roasting temperature was below $550^{\circ} \mathrm{C}$.

\section{Acknowledgements}

The author gratefully acknowledges the financial support of Jilin Province Wan Guo Gold Co. Ltd. (Ji’an, China).

\section{References}

[1] Habashi, F. (2003) Review: Textbook of Pyrometallurgy. Russian Journal of Applied Chemistry, $76,337$. http://dx.doi.org/10.1023/A:1024647906382

[2] Han, K.N. (2003) The Interdisciplinary Nature of Hydrometallurgy. Metallurgical and Materials Transactions B, 34, 757-767. http://dx.doi.org/10.1007/s11663-003-0082-1

[3] Pradhan, N., Nathsarma, K.C., Srinivasa Rao, K., et al. (2008) Heap Bioleaching of Chalcopyrite: A Review. Minerals Engineering, 21, 355-365. http://dx.doi.org/10.1016/j.mineng.2007.10.018

[4] Amaral, F.A.D., dos Santos, V.S. and Bernardes, A.M. (2014) Metals Recovery from Galvanic Sludge by Sulfate Roasting and Thiosulfate Leaching. Minerals Engineering, 60, 1-7. http://dx.doi.org/10.1016/j.mineng.2014.01.017

[5] Arslan, C. and Arslan, F. (2002) Recovery of Copper, Cobalt, and Zinc from Copper Smelter and Converter Slags. Hydrometallurgy, 67, 1-7. http://dx.doi.org/10.1016/S0304-386X(02)00139-1

[6] Rossini, G. and Bernardes, A.M. (2006) Galvanic Sludge Metals Recovery by Pyrometallurgical and Hydrometallurgical Treatment. Journal of Hazardous Materials, 131, 210-216. http://dx.doi.org/10.1016/j.jhazmat.2005.09.035

[7] Wang, M. and Wang, X. (2010) Extraction of Molybdenum and Nickel from Carbonaceous Shale by Oxidation Roasting, Sulphation Roasting and Water Leaching. Hydrometallurgy, 102, 50-54. http://dx.doi.org/10.1016/j.hydromet.2010.02.001

[8] Zhang, Y., Yu, X. and Li, X. (2011) Zinc Recovery from Franklinite by Sulphation Roasting. Hydrometallurgy, 109, 211-214. http://dx.doi.org/10.1016/j.hydromet.2011.07.002

[9] Prasad, S. and Pandey, B.D. (1999) Sulphation Roasting Studies on Synthetic Copper-Iron Sulphides with Steam and Oxygen. Canadian Metallurgical Quarterly, 38, 237-247.

[10] Xu, B.S. and Li, M.Z. (2012) Copper Smelting Process. Chemical Industry Press, Beijing, 199-200. (In Chinese)

[11] Tumen, F. and Bailey, N.T. (1990) Recovery of Metals from Copper Smelter Slags by Roasting with Pyrite. Hydrometallurgy, 25, 317-328. http://dx.doi.org/10.1016/0304-386X(90)90047-6 
Scientific Research Publishing (SCIRP) is one of the largest Open Access journal publishers. It is currently publishing more than 200 open access, online, peer-reviewed journals covering a wide range of academic disciplines. SCIRP serves the worldwide academic communities and contributes to the progress and application of science with its publication.

Other selected journals from SCIRP are listed as below. Submit your manuscript to us via either submit@scirp.org or Online Submission Portal.
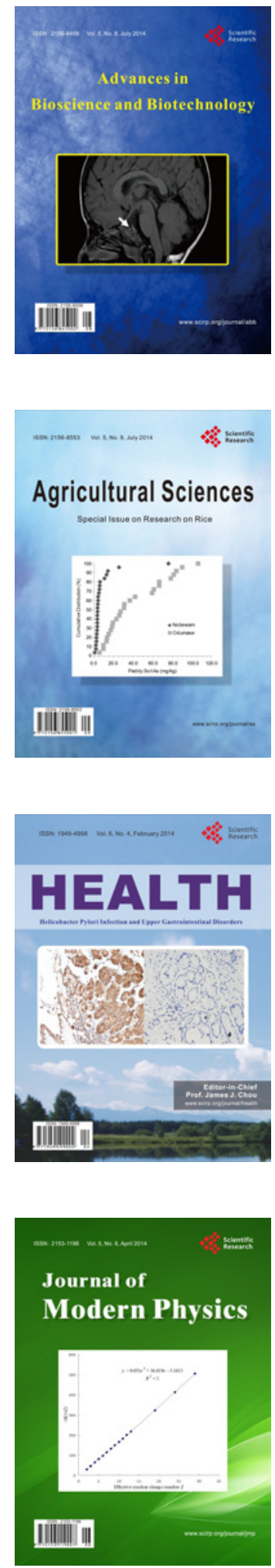
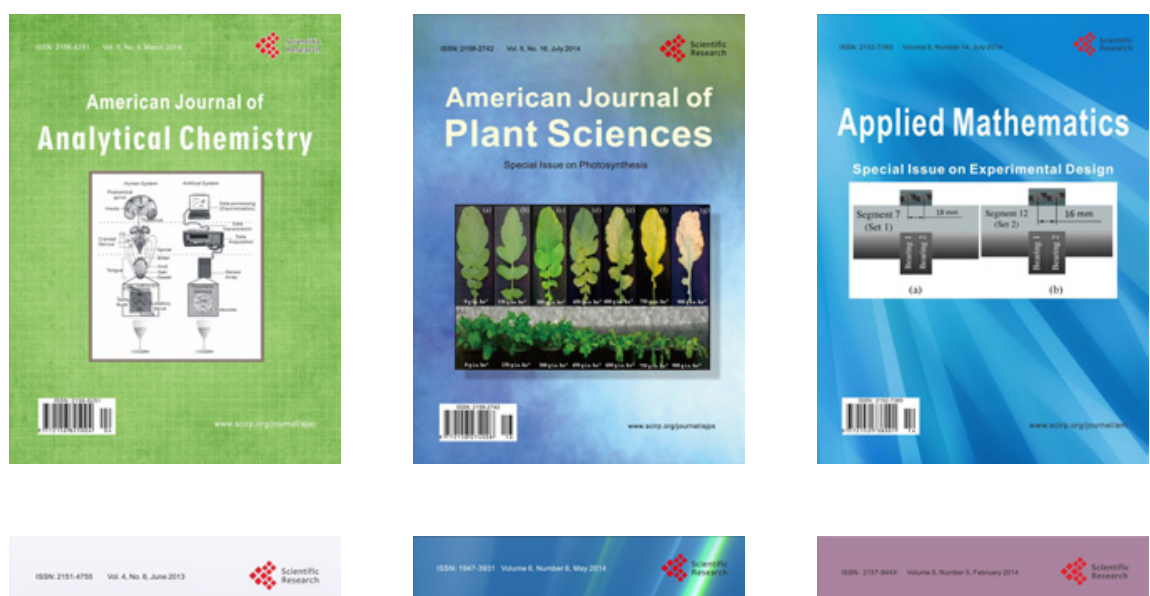

Creative Education
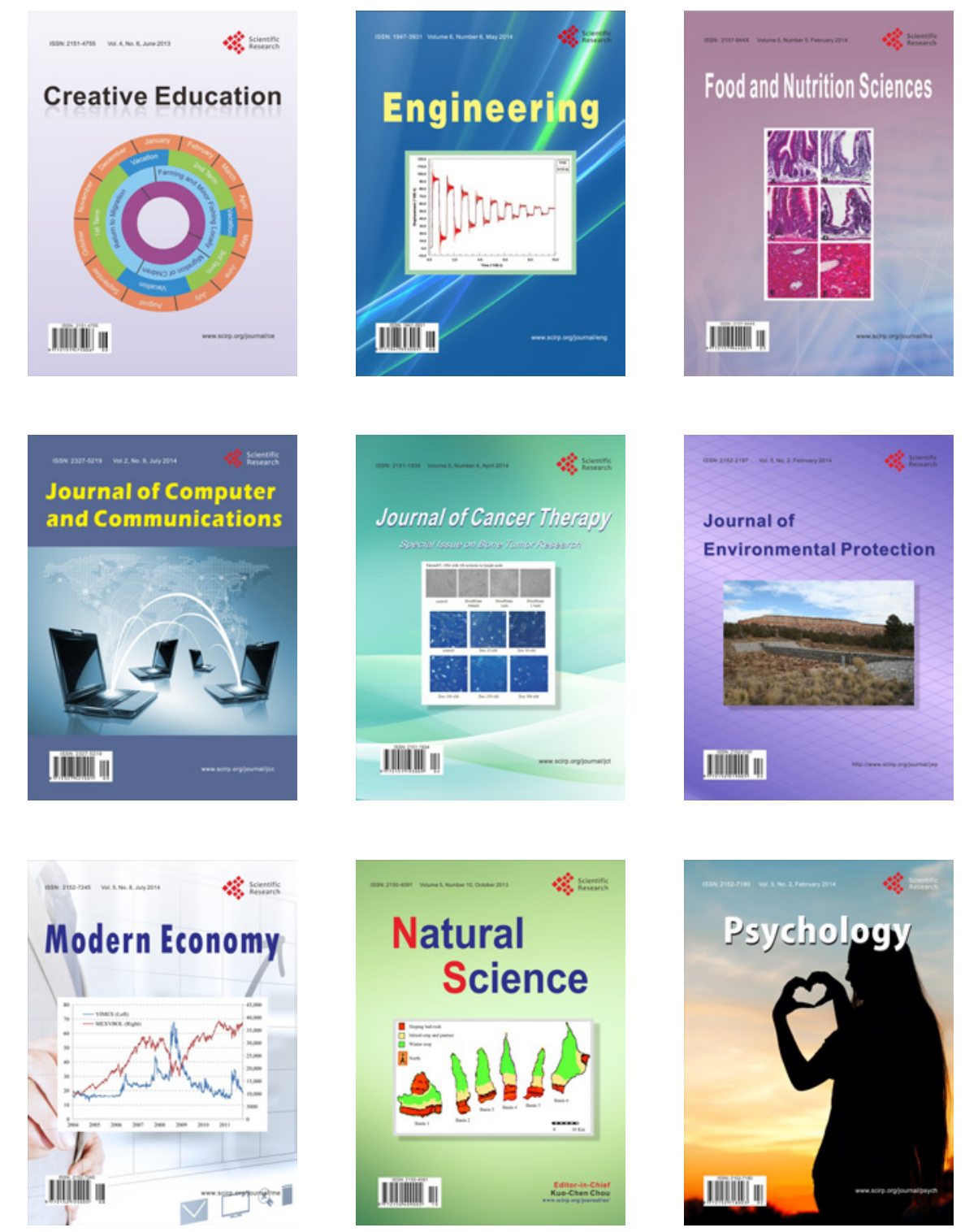